\title{
References:
}

1. Dunaina, I. (2016). Zhinochi prykrasy Perejaslavshhyny [Women's jewelry of Pereyaslav's land]. Nizhinska Starovina: Collection of Regional History and Memorial Science. Nizhyn-Kyiv: Center of Memorial Science of the National Academy of Sciences of Ukraine and Ukrainian Society of the Protection of Historic and Cultural Monuments, vol. 22(25), pp. 101-108.

2. Dunaina, I. (2018). Tvorchyj spadok siljsjkykh zolotariv u kolekciji ukrajinsjkykh narodnykh zhinochykh prykras z Cherkashhyny [Creative legacy of rural goldsmithes in the collection of Ukrainian folk women's jewelry from Cherkasy's region]. Nizhinska Starovina: Collection of Regional History and Memorial Science. Nizhyn-Kyiv: Center of Memorial Science of the National Academy of Sciences of Ukraine and Ukrainian Society of the Protection of Historic and Cultural Monuments, vol. 25(28), pp. 109-115.

\section{MUSEUM OF UKRAINIAN TOWEL NATIONAL HISTORICAL-ETHNOGRAPHIC RESERVE «PEREYASLAV»}

\section{Natalia Zaika ${ }^{1}$}

DOI: https://doi.org/10.30525/978-9934-588-11-2_25

Birth of a child and christenings, betrothal and weddings, seeing off and meeting dear guests - all these rituals were accompanied by a towel. Its ornaments contain ancient magical signs: images of the Tree of Life, Savers (Beregini), symbols of earth, water, celestial luminaries, which were further embodied and developed in a variety of customs and rituals. As a saver (oberig) the towel was transferred from family to family, from generation to generation. The Museum of Ukrainian Towel is located on the territory of the Museum of Folk Architecture and Mode of Life, in the northern part of Middle Dnieper area. The exposition, which was opened in 1995, is located in the building of the Three-Holy Church built in 1651 and moved from the village Pyshchiki of the Skvyra district of Kyiv region. Creating a permanent museum exhibit in a church room is connected with preserving the church as a monument of folk wood architecture and the need to demonstrate a unique collection of towels. In the 1960s and 1970s, when the Soviet authorities massively closed and destroyed churches, the question arose as to how to prevent this. In many cases, such premises were used to create museum facilities. The pereyaslav museums, headed by M. Sikorsky, also did this. The author of this article has published information about the temple [1], museum items on display [2;3;5], and about some aspects of museum formation [4]. The purpose of the study is to highlight the process of forming a collection of towels, the establishment and development of the Museum of Ukrainian Towel, as well as to promote the monument of architecture in which it is housed.

M. Sikorsky, director of the Pereyaslav National Historical and Ethnographic Reserve, said: «We have been collecting this good since 1952. If you knew how many villages our tireless women went: E. Nesterovskaya, I. Scotnikova,

\footnotetext{
${ }^{1}$ National Historical and Ethnographic Reserve «Pereiaslav», Ukraine
} 
M. Chukhno, O. Yuzvikova, O. Rak and S. Sobol. Then they were joined by V. Shkuleta, M. Ermoliev, M. Shaveiko, V. Yuzvikov, M. Zham. That is why we have such wealth - the whole history of the Ukrainian towel» [8].

For many years of collecting and research work the Reserve has been pleased to collect 3944 original towels from different regions and districts of Ukraine.

With such wealth, Mikhail Ivanovich was born with the idea of creating a Towel Museum. Since December 1994, work has begun on the creation of an exhibition of the Museum of Ukrainian Towel. Scientific substantiation was written, structural and thematic-exposition plans were drawn up. According to the first, towels were organized according to regional features, technique and dating. The second stage of the work was to sew loops (over a thousand) on towels. In May 1995, the Museum of Ukrainian Towel was opened.

The exposition occupies three halls - the altar, the «nava» and the «babinets». The first hall exhibits the famous perejaslav towels of the 19th - early 20th centuries, although their ornamentation dates back to ancient times. Pereiaslav woven towel is a unique page in the history of Ukrainian folk art. In the past, Pereyaslav Region was one of the weaving centers in Ukraine. Towels were woven in every home, every village, but in the county there were several villages in which weaving became industrial (Letski, Vinentsi, Pomokli, Strokova and Velyka Karatul). In the villages Vinentsi and Velyka Karatul weave to this day (the works of craftswomen from these villages are exhibited in the altar). The works of the Pereyaslav masters are unique in their compositional richness and size: the ends of the towels were almost completely filled with horizontal, vertical and reticulated stripes or continuous ornament. Among the great variety of woven towels are Krolevets towels that are displayed in the second hall. Red and ornamental elements which have saving (oberig) meaning make them festive and ceremonial. Without them, no significant event in the life of Ukrainians was complete. The ceremonial role of the Krolevets towel was determined by a number of amulet symbols-oberigs: two-headed eagles (sign of the sky deer); bowls (Goddesses-Beregines); bell-churches-monastirki.

These ornaments were applied on the canvas by the hands of master craftsmen who lived in the vicinity of Krolevets and Romain. In the middle of the nineteenth century the first manufactories for the production of the famous Krolevets towel emerged. He gained fame not only in the Russian Empire, but also abroad. The arches of the church are decorated with ancient woven Polissia towels of the XIX century. Their ornamentation is characterized by the horizontal arrangement of the pattern, with predominant black, red colours and sometimes a sprinkling of blue tones. A large museum collection - embroidered towels by various techniques. The most ancient and the most interesting of them in artistic terms are the products that are embroidered with towel seams, the so-called Poltava towels (XIII-XIX centuries). This group includes towels of the ancient Poltava region (Pereyaslav region, part of Cherkasy region) and Poltava ethno-region. Particularly interesting in the collection are «monastery» or «monks» towels, early XIX - early XX century. (Chigirin, Lubny, partly Pereyaslav region). These are unique works of folk art. They are distinguished in the composition asymmetry, in ornamentation - stylization of plant 
forms to geometric ones; the presence of anthropo-, zoo- and ornithomorphic forms and other signs-symbols. This transforms the household item into a ritual, ritual attribute: a towel for such events as births, weddings etc. The exhibition blends in with the architecture of the temple, giving the Museum not only beauty but also spirituality. The Ukrainian Towel Museum is a museum in which the soul is tempted, as evidenced by the book of impressions and wishes [7]. During the years of the Museum's operation, exhibitions have been opened, in particular «Monastery Towels» (2002); Towels of the Flooded Villages of Pereyaslav Region (2008); «The author's work on stencil of the master Chornobay» (2015) and others. The attendance of the museum is significant: every year, over four thousand sightseers visit the Museum. The Museum of Ukrainian Towel holds cultural events. So, on the occasion of the 20th anniversary of the Museum's creation, on September 26, 2015, they held an All-Ukrainian action of embroidering the unity towel - «Let's hug, my brothers!» The Ukrainian Towel Museum fits in harmoniously with the wooden interiors of the Three Saints Church, combining ethnographic history of Ukrainian. Towels as an ethnographic material are studied by students, art critics, they are a model for modern designers and fashion designers. Each towel is unique, because there is not a single model in the exhibition, and only authentic samples of folk embroidery are presented.

\section{References:}

1. Zaika, N. L. (2006). Tserkva iz sela Pyshchyky - pamiatka narodnoi arkhitektury XVII st. [Church from the village of Pyschyky - a monument of folk architecture of the 17th century]. Proceedings of the Temples of Pereyaslav Region: history, traditions, modernity; the state of saving the monuments. Pereyaslav-Khmelnitsky.

2. Zaika, N. L., Cherednichenko, L. S. (2007). Monastyrski rushnyky z kolektsii Natsionalnoho istoryko-etnohrafichnoho zapovidnyka «Pereiaslav» [Monastic towels from the collection of Pereyaslav National Historical and Ethnographic Reserve]. Proceedings of the Mohylanski Readings 2006: Collection of Scientific works: The fate of museum collections / National KievPechersk historical and cultural reserve; editorial board: V.K. Kolpakova (editor in chief) and others. Kyiv: Phoenix.

3. Zaika, N. L. (2011). Vybiika na Pereiaslavshchyni kintsia XIX - seredyny XX st. (za fondovoiu kolektsiieiu NIEZ «Pereiaslav») [Stencil (Vyboyka) in Pereyaslav region late XIX mid XX century. (based on the «Pereyaslav» NIEZ stock collection)]. Proceedings of the Ukrainian art: materials, studies, reviews: Collection of Scientific works. Kyiv, vol. 11, pp. 31-35.

4. Zaika, N. L. (2016). Do istorii stvorennia muzeiu ukrainskoho rushnyka [To the history of the creation of the museum of the Ukrainian towel] Proceedings of the Regional Studies of Pereyaslav Region: Studies, Problems, Figures: Round Table Materials, October 16, 2015, PereyaslavKhmelnytskyi / [Editorial board: O.V. Kolibenko and others; compiler T. Nagayko]. PereyaslavKhmelnitskyi: Dombrovskaya Ya. M., vol. 3, pp. 54-63. (Series «Local History Library of Pereyaslav Region»).

5. Zaika, N. L. (2017). «Krolevetski» rushnyky kintsia XIX - pochatku XX st. v ekspozytsii Muzeiu ukrainskoho rushnyka Natsionalnoho istoryko-etnohrafichnoho zapovidnyka «Pereiaslav» [«Krolevets» towels of the late XIX - early XX centuries in the exposition of the Museum of Ukrainian Towel of the National Historical and Ethnographic Reserve Pereyaslav]. Collection of Scientific works Siverschina region in the history of Ukraine. National Hlukhiv Reserve. NASU and UTOPIK Center for Monuments. Kyiv; Hlukhiv.

6. Kamenskaya, N. G. (1987). Pro mynule mista i yoho zavtrashnyi den [About the city's past and its tomorrow] The Communist Labor. July 25, p. 2. 
7. Knyha vrazhen ta pobazhan Muzeiu ukrainskoho rushnyka za 1995-2002 rr. [The Book of Impressions and Wishes of the Ukrainian Towel Museum for 1995-2002].

8. Makhinchuk, M. G. (1998). Oberehy nashoi pam'iati: Knyha dlia chytannia z istorii Ridnoho kraiu [Savers (Oberig) of our memory: A book for reading on the history of the Native land] / Preface by I. F. Drach. Odessa: RBA «Aspect».

\section{THE PIANO FANTASIES BY V.A. MOZART IN THE CONTEXT OF PHILOSOPHICAL AND POETIC CONCEPTS OF IMAGINATION}

\section{Elena Pogoda ${ }^{1}$}

DOI: https://doi.org/10.30525/978-9934-588-11-2_26

By the end of the 18th century, the phenomenon of fantasy receives multifaceted understanding, while being developed as a philosophical category and as a genre that embraces music, literature, poetry, theatre, and visual arts.

The philosophical development of imagination and fantasy of the end of the 18 th century can be found in the works by I. Kant of 1781-1798 [1], the first of which was written almost simultaneously with the piano fantasies by V.A. Mozart. I. Kant identifies the types of fantasies that manifested themselves in music. Such are fantasy as contemplation (a contemplative beginning is inherent in fantasy), a dream (its characteristic features are fragmented kaleidoscopic images), playing (a playing method as a way to create an artistic image - the fundamental one for fantasy). The functions of fantasy - illusory, transforming, associative, transcendental, synthesizing, were embodied in the creative work of V.A. Mozart.

In the theory of literature at the end of the 18th century, the concepts of fantasy as a fundamental type of artistic creation were developed in the legacy of English romantics - S.T. Coleridge and W. Wordsworth. Imagination is the ability to synthesize perceptions of various kinds. The function of fantasy, according to S.T. Coleridge is in "collecting the diverse experiences of being according to the laws of associations» [2, p. 28]; fantasy is the ability to bring together images that do not have natural connections, but are connected by a poet «according to the principle of a random coincidence» [2, p. 62]. Imagination «modifies images, gives unity to diversity and focuses everything in one». W. Wordsworth notes that fantasy «helps to comprehend the essence of things and characters immeasurably deeper» [3, p. 142]. The piano fantasies by V.A. Mozart were created during the last - the climax of the composer's creative work. The fantasy trilogy of 1782 (fantasy and fugue C-dur $394 \mathrm{KV}$, fantasy c-moll $396 \mathrm{KV}$ and d-moll $397 \mathrm{KV}$ ) marked the beginning of a mature stage in the composer's creative work, the fantasy and sonata c-moll of $1785(475 \mathrm{KV})$ coincided with the era of writing opera masterpieces (the end of the work on «The Wedding of Figaro» and the beginning of work on «Don Juan»).

${ }^{1}$ Kharkiv National Kotlyarevsky University of Arts, Ukraine 